\title{
Rewriting second- and third-century history in late antique Rome: the Historia Augusta
}

\author{
ANTHONy R. BiRLEY \\ Universität Düsseldorf \\ Germany
}

Resumo. Reescrevendo a história dos séculos II e III na Roma Antiga: a "Historia Augusta". O ensaio resume inicialmente as opiniões atuais acerca das origens da História Augusta. Em seguida, a estrutura da obra é examinada; possivelmente tanto a falta de prefácio quanto a "lacuna" para os anos de 244-260 são deliberadas. Muitas partes do texto são fictícias, principalmente as "vidas secundárias" e as personalidades do século III. As passagens ficcionais, nas quais a história do período anterior a Diocleciano foi reescrita, são importantes para a compreensão da mentalidade do autor desconhecido: ele era hostil a Constantino e ao Cristianismo, mas grande admirador de Diocleciano. Há muitas marcas de humor, particularmente os pseudônimos 'Trebellius Pollio' e 'Flavius Vopiscus Syracusius', cuja escolha é explicada. Mas, apesar desses gracejos, o autor é sério ao desejar que surja um segundo Diocleciano, que poderia restabelecer os valores tradicionais e a religião da antiga Roma.

Palavras-chave. História Augusta; fontes factuais; história ficcional; hostilidade a Constantino e ao Cristianismo; admiração por Diocleciano; apreço ao humor; escolha de pseudônimo como sinal de humor; anseio por um novo Diocleciano e por restauração pagã.

In what follows the late date of writing, after 395, and single authorship of the Historia Augusta $(H A)$ are taken for granted. Hardly anyone now seems to believe in the ostensible date of composition, under Diocletian and Constantine, or, indeed, in the existence of six separate authors. What is perhaps the most interesting feature of the work is not so much the sources, Quellen, for 'facts' but the inspiration, Anreger, for the fiction, and the mentality and intentions of the author. But first, something on Quellenforschung. In 1978 Barnes distinguished 'six main sources' for all the 'authentic historical information about the second and third centuries': Ignotus, 'the basic source as far as 217'; Marius Maximus, 'used to enliven Ignotus as far as 217, probably drawn on in the Macrinus, and the main source of the Heliogabalus'; Herodian, 'the basic source for 238, but also used earlier'; Dexippus, 'the basic source from mid-238 to 270'; the lost Kaisergeschichte; Eunapius, 'the Greek source whose use can be detected after 270'. In his 1992 survey, he concedes 
that ' $[\mathrm{t}]$ he identification of Eunapius as the Greek source after 270 was overconfident' and he 'would now admit Victor and Eutropius as sources on the same level as the lost Kaisergeschichte." Not many are prepared to accept the existence of Ignotus, conjured up by Syme with the enthusiastic support of Barnes; most seem content with Marius Maximus as the main source for the lives from Hadrian to Caracalla or even Elagabalus. And others now prefer to substitute for Eunapius another Latin source, the lost Annales of Nicomachus Flavianus. See on all this Paschoud, in the introduction to his latest commentary: as he says, the battle for the Kaisergeschichte is practically won, the only dispute being over its terminal date, 337 or 357 . There is less agreement on the Annales of Nicomachus Flavianus, which he also discusses there, as well as, less controversially, the use of Dexippus. ${ }^{2}$

It is impossible to offer more than selective comments here. Of the three sources that survive in full only Herodian is named (to have cited Victor and Eutropius would have sabotaged the pretence to be writing before their time). Herodian was used far more than is stated, three times cited as 'Arrianus' against ten as 'Herodianus', either to mislead, or to multiply sources, or perhaps by inadvertence. ${ }^{3}$ As Kolb shows, very often the $H A$ distorts Herodian. ${ }^{4}$ The effect is sometimes impressive. Gibbon remarked of discordiae...sed tacitae, et quae intelligerentur potius quam viderentur (MB 14.1) that 'this well-chosen expression is probably stolen from some better writer. ${ }^{5}$ Note further Brandt's comment on MB 15.3, haec sunt, quae de Maximo ex Herodiano, Graeco scriptore, magna ex parte collegimus: 'Diesem Satz kommt die Bedeutung einer Schlüsselaussage in puncto Quellenbenutzung zu.' He cites as a key statement of intent $G d$. 21.4: si quidem ea debeant in historia poni ab historiografis, quae aut fugienda aut sequenda ${ }^{6}$ On Victor and Eutropius, Dessau's original demonstration that Sev. 17.5-19.4 was copied from from Victor, Caes. 20.1 and 10-30, and MA 16.3-18.2 from Eutropius 8.11 is now generally accepted, and needs no further discussion here?

${ }^{1}$ T.D. BARnes, The Sources of the Historia Augusta (1978); id., HAC n.s. III (1994) 1-34.

${ }^{2}$ F. Paschoud, Histoire Auguste V.2, Vies de Probus...Carin (2001) XIIff.; id., HAC n.s. I (1992) 217-269.

${ }^{3}$ Cf. W. HartKe, Römische Kinderkaiser (1951) 379 n.2; J. Straub, Studien zur Historia Augusta (1952) 23, 156 n.122; BARNES, Sources 37; R. Syme, Emperors and Biography (1971) 172f.; H. BRAndT, Kommentar zur vita Maximi et Balbini der Historia Augusta (1996) $118 \mathrm{f}$.

${ }^{4}$ F. KolB, Literarische Beziehungen zwischen Cassius Dio, Herodian und die Historia Augusta (1972), passim; id., HAC n.s. III (1995) 179-191.

${ }^{5}$ E. Gibbon, The History of the Decline and Fall of the Roman Empire I (1776), ch. 7. Cf. Syme, Emperors 119.

${ }^{6}$ BRAndt, Kommentar 228; 39.

${ }^{7}$ H. Dessau, Hermes 24 (1889) 363-370; see A. Chastagnol, Histoire Auguste. Les 
On Marius Maximus, I must confess to being a believer, and can claim fairly widespread support. ${ }^{8}$ But a few years ago Paschoud dissented radically, and argued that Maximus was probably a satirical poet, like Juvenal and not the author of vitae Caesarum at all. He evidently regards the Maximus quoted in the HA as yet another 'fausse autorite [thirty-five on the standard count]'. On my claim, "but in the case of Marius Maximus that would have been self-defeating", he remarks that 'j'avoue mal comprendre cette affirmation. ${ }^{9}$ My point was that since Ammianus (28.4.14) says that the aristocracy, detesting doctrinas like poison, read nothing except Juvenal and Marius Maximus, it would have been self-defeating to invent imperial biographies by such a well known author, if he was really a poet like Juvenal. ${ }^{10}$ Paschoud notes that three out of four passages indicating that the author of the $H A$ knew the Scholia on Juvenal come from those on 4.31-81, the part in which the Scholia cite Marius Maximus (on 4.53); the other one is on 12.103. ${ }^{11}$ But, one may argue, perhaps the inspiration for 'Palfuerius' in Gall. 18.6 was Maximus' Vita Nervae, not the Scholia. One may further note the Schol. on 7.243, which resembles $M A 11.4$, as pointed out by Schwartz. Cameron plausibly inferred that both Scholiast and $H A$ drew here on Maximus' vita Marci. ${ }^{12}$ The jibe that Maximus wrote mythistorica volumina ( $Q T$ 1.2) just refers to MA 1.5-6, Marcus' descent from Numa and Malemnius, Dasummi filius, also in Eutropius 8.9.1 — but shorter.

Some remarks are needed about the structure of the work. It opens in medias res, with the origin of Hadrian. There is no Preface, or none has survived; and no vitae of Nerva and Trajan. Have a Preface and lives of Nerva and Trajan been lost in transmission? There is no obvious means of discov-

empereurs du II et $I I I^{e}$ siècles (1994) LXVIff., for further passages based on Victor and Eutropius.

${ }^{8}$ A.R. Birley, $A N R W$ II 34.3 (1997) 2678-2757. It must be conceded that at least one argument (from the use of the ablative absolute with present participle) there put forward to identify possible use of Maximus is mistaken, being based on false statistics (as F. Paschoud has pointed out to me). In support of Maximus as a source of the $H A \mathrm{cf}$. CHASTAGNOL, Histoire Auguste LIIIff.

${ }^{9}$ F. PAschoud, HAC n.s. VII (1999) 241-254. The quotation is from p. 242, citing BiRLey 2682.

${ }^{10} \mathrm{~A}$ similar view is put forward by Z. RuBIN, Civil-War Propaganda and Historiography (1980) 139f.: 'The authenticity of the references to Marius Maximus may be upheld...This is precisely the period in which Marius Maximus' biographies were immensely popular [citing Amm. Marc. 28.4.14 and Schol. Iuv. 4.53]. Would the author have given the game away by deliberately faking quotations of such a well known writer in his own day and age?'. (RuBIN, as a believer in Syme's Ignotus, of course takes a different view, which I do not share, about the extent to which Maximus was a source for the $H A$.)

${ }^{11}$ Paschoud, op. cit. (n.9) 252f.

${ }^{12}$ J. Schwartz, Historia 15 (1966) 458; A. CAMERon, JRS 61 (1971) 266. 
ering the answer. ${ }^{13}$ A comparable mystery is the lacuna between Gordiani tres and Valeriani duo, the latter, as it stands, beginning with Valerian's fate, followed by some retrospective material. The years 244-260, with lives of Philip, Decius and Trebonianus Gallus and their respective sons, Aemilianus, and Valerian's reign from 253-260, are not covered. Over thirty years ago I suggested that the lacuna was spurious. ${ }^{14}$ The most recent discussion is favourable to the idea..$^{15} \mathrm{~A}$ false lacuna would have liberated the author from treating Philip, later claimed as a Christian, and Decius and Valerian, major persecutors - and the fate of the latter two, interpreted by Christians as divine retribution. Both Decius and Valerian are treated extremely positively in the $H A$. Be this as it may, religion of various kinds takes up a good deal of space in the work. ${ }^{16}$ The lack of preface and the lacuna may both be spurious, designed to support the imposture.

Over thirty years ago Alan Cameron conjectured that the author of the $H A$ initially set out to compose a continuation of Maximus, just as Maximus had continued Suetonius; but that then, discovering his talent for fiction, he had a brainwave, to add add new Caesars to Maximus. ${ }^{17}$ Syme argued against this, arguing particularly that $A S 35.1$ seems to presuppose $P N 11.6$, and that $\mathrm{Hel}$. and $A S$ are so closely interrelated that it is hard to believe that $A S$ was composed first and Hel. at the very end of the process. ${ }^{18} \mathrm{~A}$ simpler proposal is that the author simply saw a gap in the market. Maximus was very popular, but excessively longwinded. The author would produce a com-

${ }^{13}$ For different views see HartKe, Römische Kinderkaiser 326ff.; J. Schlumberger, BHAC 1972/74 (1976) 201-219, at 209; D. DEN Hengst, The Prefaces in the Historia Augusta (1981); K.-H. StubenRauch, Kompositionsprobleme der Historia Augusta (Einleitungen Der verlorene Anfang) (1982) 59ff.; M. MECKLER, Historia 45 (1993) 364-375.

${ }^{14}$ A.R. BirLEY, BHAC 1972/74 (1976) 55-64, expanding on a suggestion by id., in T.A. Dorey, ed., Latin Biography (1967) 113-138, at 125f., in answer to criticism by Syme, Emperors 199-202.

${ }^{15}$ The expanded treatment was favoured by DEN Hengst, op.cit. 70-72; treated with reserve by Stubenrauch, op.cit. 100-104, and Chastagnol, Histoire Auguste XLII-XLIV; regarded as seductive by PASCHOUd, Histoire Auguste V.1, Vies d'Aurélien et de Tacite (1996) XXIX, cf. 68, 200; and supported at length with new arguments by S. RATTI, Histoire Auguste IV.2, Vies des Valériens et des deux Galliens (2000) VII-XXVIII. Inter al. he notes the point made by A. Chastagnol, HAC n.s. III (1995) 139-150, at 150, that the long account of the censorship, offered to Valerian by Decius, is out of place at Val. 5.2-6.9.

${ }^{16}$ A.R. Birley, HAC n.s. I (1992) 29-51. F. Paschoud, in F. Chausson and E. WolfF, edd., Consuetudinis amour. Fragments d'histoire romaine (IIe-VIe siècles) offerts à J.-P. Callu (Rome 2003) 357-369.

${ }^{17}$ In his review of R. Syme, Ammianus and the Historia Augusta (1968), JRS 61 (1971) 254-267, at 266f.

${ }^{18}$ R. Syme, JRS 62 (1972) 123ff., repr. in id., Historia Augusta Papers (1983) 12ff., at 18f., 21ff. D. DEN HENGST, HAC n.s. III (1995) 151-167, at 161, 165f., supports Cameron; but does not discuss the place of $\mathrm{Hel}$. in this scheme. 
pact version, spiced up by adding vitae of figures not treated separately by Maximus - and 'improving' Maximus with fiction, unobtrusively tucked in here and there in the 'primary' lives based on Maximus, wholesale in the 'secondary' lives. He then produced a new set of lives, beginning where Maximus left off. The early lives, based on Maximus, were concocted at speed - by dictation (as indeed was the case with the whole work). The need to condense a very long source made the author impatient in places: he cut drastically and substituted convenient summaries from Victor and Eutropius. His haste, and the need to excerpt suitable parts of Maximus' lives for the new ones that he was adding, Aelius, Verus, Avidius Cassius, etc., resulted in incoherence, repetition and muddles. With MAnt, he abbreviated too much, having exploited his source to create separate lives of L. Verus and Avidius Cassius, and after using a piece of Eutropius, decided to add more.

In the 'post-Maximus' part, Herodian was exploited, up to 238, Dexippus for the years 238-270 or 275, then perhaps Flavianus; and the author could always turn to the Kaisergeschichte for further material. But the 'secondary lives' in the first part and those from Val. onwards were predominantly fictional. As calculated by Paschoud, the amount of serious historical information in the last five vitae is as follows: $26.6 \%$ in Aur., 15.3\% in Tac., $16.8 \%$ in Prob.; nil in $Q T ; 17.2 \%$ in $C a r .{ }^{19}$ On a rapid count, one might add approximate percentages for some other vitae: Ael. c. 25\%; $A C, G$ and $D d$ just over 5\%; PN 28.8\%; ClA 32.1\%; OM c. 33.3\%; Hel. c. 24\%; AS just over $4 \%$; Cl. c. $10.25 \%$.

The author began to insert pieces of fiction and various sententious remarks in the lives of second-century figures. There was infinitely more scope in third-century lives, but even in second-century ones some rewriting can be detected. At $H 22.10$, pontificis maximi officium peregit, it is hard not to see implied comment on Gratian's abdication from that officium. In $A C$ he put aphorisms in the mouth of Marcus Aurelius, e.g. 8.5: in imperatore avaritiam esse acerbissimum malum; 12.5 : non enim umquam placet in imperatore vindicta sui doloris, quae si iustior fuerit, acrior videtur; 11.5: non enim quicquam est, quod imperatorem Romanum melius commendet gentibus quam clementia. At Sev. 17.1 there is the clearly fictitious statement at 17.1: Iudaeos fieri sub gravi poena vetuit. idem etiam de Christianis sanxit; and the last chapters of this vita are mainly fictional.

The author could also praise Diocletian in the earlier lives, beginning at Ael. 1.1, where he addresses him as tot principum maxime. At MAnt 19.12, he claims Marcus is 'even now regarded as a god' by Diocletian, and adds

${ }^{19}$ Paschoud, Vies de Probus... 301.

Classica, Belo Horizonte, v. 19, n. I, p. 19-29, 2006 
the latter's supposed frequent remarks on the subject. Diocletian is made to stress clementia here, a theme reiterated in the $A C$ (quoted above); one may note also Verus 11.4. Diocletian's interest in and respect for his precedecessors, quia te cupidum veterum imperatorum esse perspeximus, OM 15.4, may be meant to contrast with Constantine's known mockery of Augustus, Trajan, Hadrian, M. Aurelius and Severus. ${ }^{20}$ Then there is the distaste for hereditary rule, already expressed at MAnt 21.5-6; it is directed to Diocletian at Sev. 20.4. At Hel. 35.4 Diocletian is called aurei parens saeculi. The positive attitude to Diocletian reaches a climax in the last vita. First, Car. 10: vir rei $p$. necessarius; then 13.1: virum insignem, callidum, amantem rei p., amantem suorum et ad omnia, quae tempus quaesiverat, temperatum, consilii semper alti, nonnumquam tamen <ferae $>$ frontis, sed prudentia et nimia pervicacia motus inquieti pectoris conprimentis; finally 18.4, the panegyric on the tetrarchs: quattuor sane principes mundi fortes, sapientes, benigni et admodum liberales, unum in rem $p$. sentientes, $s<e m>$ per reveren $<$ tes $>$ Romani senatus, moderati, populi amici, $<s e m>$ pe $<r>s<a n>c t<i>$ tate graves, religiosi et quales principes semper oravimus. ${ }^{21}$ The presentation of Constantine is rather different. The first two addresses are neutral (ClA 4.1, G 1.1). At Hel. 34.1ff. comes a lengthy one, matched by that at $A S$ 65.1-68.3, with the highly unflattering statement that Constantine used to be subject to eunuchs (67.1). Parody of Constantine has been detected throughout the Hel. 3.4-5:

id agens, ne quis Romae deus nisi Heliogabalus coleretur....dicebat praeterea Iudaeorum et Samaritanorum religiones et Christianam devotionem illuc transferandam, ut omnium culturarum secretum Heliogabali sacerdotium teneret; 6.6, sacra populi Romani sublatis penetralibus profanavit; 6.7, nec Romanas tantum exstinguere voluit religiones, sed per orbem terrae, unum studens, ut Heliogabalus deus ubique coleretur; 6.9, signum tamen quod Palladium esse credebat abstulit; 15.7, deinde in Capitolium ad vota concipienda et perficienda solemnia ire noluit; 23.1, et elephantorum quattuor quadrigas in Vaticano agitasse dirutis sepulchris quae obsistebant; 23.5 , voluit uti et diademate gemmato; 24.7 , constituerat et columnam unam dare ingentem, ad quem ascenderetur intrinsecus, ita ut in summo Heliogabalum deum collocaret. ${ }^{22}$

${ }^{20}$ This respect matched that of Theodosius towards the Antonines, especially Trajan. For Constantine's mockery of his predecessors see Epit. de Caes.41.13 (Trajan) and Anon. post Dionem fr. 15.2 (a fuller list, breaking off with Severus), discussed by B. BLECKMANN, Historia 40 (1991) 356, 361 and ibid. 44 (1995) 97f., citing, by contrast, Pacatus, PL 12 (2). 11.6, Theodosius as the 'Vollender der mit Augustus einsetzenden Reihe guter Kaiser'.

${ }^{21}$ See F. KolB, Untersuchungen zur Historia Augusta (1987) 6-9. For the text of Car. 13.1 and 18.4 see Paschoud, Vies de Probus..., ad loc.

${ }^{22}$ T. Optendrenk, Die Religionspolitik des Kaiser Elagabal im Spiegel der Historia 
Christian scripture is parodied in $A S$ : at 13.5, the stella primae magnitudinis visa; 14.4, nam ubi est imperium nisi apud Romanos, quod tenet imperium? (cf. II Thess. II 2. 6-7). Alexander is implicitly contrasted with Constantine at 43.5:

Capitolium septimo quoque die, cum in urbe esset, ascendit, templa frequentavit; 43.6-7, Christo templum facere voluit eumque inter deos recipere. quod et Hadrianus cogitasse fertur, qui templa in omnibus civitatibus sine simulacris iusserat fieri, quae hodieque idcirco, quia non habent numina, dicuntur Hadriani, quae ille ad hoc parasse dicebatur; 7. sed prohibitus est ab his, qui consulentes sacra reppererant omnes Christianos futuros, si id fecisset, et templa reliqua deserenda.

Note also 45.7, 49.6, on Christians and Jews; 51.7-8, on the Golden Mean. Apollonius of Tyana is bracketed with Christ at $A S$ 29.2, and recurs in detail at Aur. 24.2ff. Prob. 20.3-6 echoes Isaiah 2.4 (swords into ploughshares). ${ }^{23}$

Was this all just intended to be humorous? Syme argued that humour was the author's main purpose. Examination of the last two pseudonyms used by the author certainly reinforces the idea that the author was a joker. 'Trebellius Pollio' and 'Flavius Vopiscus Syracusius' were invented, Domaszewski first argued, on the basis of passages in Cicero: Antonius' partisan Trebellius was mentioned in the Philippics and in Ad fam. 11.13a.4, hora ante praesidium meum Pollentiam venit quam Trebellius cum equitibus, and in the latter case Pollentiam reminded the author of Asinius Pollio, by a verbal echo. ${ }^{24}$ But there is more to this than Domaszewski saw. Den Hengst, discussing Aur. 2.1-2, where 'Flavius Vopiscus' reports criticism of 'Trebellius Pollio' by the Prefect Tiberianus, ${ }^{25}$ notices that this recalls similar comments by Asinius Pollio about Caesar's Commentarii (Suet. D. Iul. 56.4). ${ }^{26}$

Augusta (1969) 55f., 132f.; R. Turcan, 'Héliogable précurseur de Constantin?', BAGB 47 (1988) 38-52; L. Cracco RugginI, 'Elagabalo, Costantino e i culti "syriaci”, HAC n.s. 1991 I (1992) 123-146; on 24.7, G. FowDEN, 'Constantine's porphyry column: the earliest literary allusion', JRS 81 (1991) 119-131, at 121.

${ }^{23}$ See F. Paschoud, in F. Chausson and É. WolfF, edd., Consuetudinis amor. Fragments d'histoire romaine...offerts à J.-P. Callu (2003) 359-369, suggesting that the author was an apostate.

${ }^{24}$ A. von Domaszewski, Die Personennamen in den Scriptores historiae Augustae, Sitz.-ber. Heidelberg 1918, 13. Abh., 11-13.

${ }_{25}$ 'Vopiscus' did not share Tiberianus' view of 'Pollio', who 'displayed his diligence by covering thirty usurpers concisely, in a single book', QT 1.2-3.

${ }^{26}$ Den Hengst, The Prefaces 106f.: 'The fact that...a verdict is given that resembles Asinius Pollio's criticism of Caesar suggests that our author had Suet. div. Iul. in mind when he wrote $A$ 2.' 
Closer attention to the Trebellius named by Cicero enables one to go beyond both Domaszewski and den Hengst. As tribunus plebis in $47 \mathrm{BC}$, L.Trebellius opposed Dolabella's bills to abolish debts and remit rents. This won him gratitude from creditors. ${ }^{27}$ When Trebellius fell into debt himself, he changed his tune, and Cicero denounced him: the shameless Trebellius had actually assumed the cognomen 'Fides' to advertise his support for 'credit', which had helped him to become aedile (Phil. 6.11). ${ }^{28}$ Further derogatory references occur at Phil. 10.22, 11.14, and 13.26. The last deserves quotation: aedilicii corycus laterum et vocis meae, Bestia, et fidei patronus, fraudator creditorum, Trebellius. Surely the author of the $H A$ was thinking of L. Trebellius Fides when he chose the name 'Trebellius Pollio': fides and fidelitas historica assume a major role precisely in the vitae assigned to 'Trebellius Pollio' and 'Flavius Vopiscus Syracusius:; ${ }^{29}$ and Trebellius' ally against Dolabella was his fellow-tribune - Asinius Pollio (Plut. Ant. 9. 1-2). ${ }^{30}$

Cicero was the writer most cited and imitated in the $H A$, especially in the last lives. ${ }^{31}$ Furthermore, ' $[\mathrm{t}]$ he influence of Cicero makes itself felt' in Aur. 2, where "the wilful distortion of the traditional veritas-topos in particular - by far the most spectacular programmatic statement in the $H A$ - is to a large extent written in imitation of Cicero' ${ }^{32}$ It is precisely at Aur. 2 that 'Vopiscus' first discusses 'Trebellius Pollio'. Fides meaning 'historical reliability' crops up sporadically in the earlier part of the $H A$. In the lives by 'Pollio' and 'Vopiscus' it is a major theme. The concern of 'Pollio' for accuracy is apparent early, in Val. 5.3, cf. Gall.14.9-10. To 'preserve fides' and 'historical fidelity' he cites translated verses on the pretender Aureolus: ut fidem servarem...ut fidelitas historica servaretur, $T$ 11.6. At the end of the $T$ he states that he has written non tam diserte quam fideliter, $T$ 33.7-8. 'Vopiscus' lays it on thick: quam fidei causa inserendam, A 12. 4; extat epistula, quam ego, ut soleo, fidei causa...inserendam putavi, A 17.1; nam ipsam [sc. epistulam] quoque indidi ad fidem rerum, A 20.4; quod...fides historica

\footnotetext{
${ }^{27}$ See on him F. MÜnZER, RE 6A.2 (1937) 2263f.

${ }^{28}$ Compare L. Antonius (cos. $41 \mathrm{BC}$ ), who at this time took the equally strange $\operatorname{cog}$ nomen 'Pietas'.

${ }^{29}$ See J. Burian, Klio 59 (1977) 285-298.

${ }^{30}$ Asinius Pollio was surely also tribune of the plebs; doubted in MRR II 287, but accepted ibid. III 26.

${ }^{31}$ Den Hengst 163; 74. See Chastagnol, Histoire Auguste LXXVIIff.

${ }^{32}$ Viz. De legibus 1.5, alias in historia leges observandas putare, alias in poemate... quamquam et apud Herodotum, patrem historiae, et apud Theopompum sunt innumerabiles fabulae, etc.; and Brutus 42, quoniam quidem concessum est rhetoribus ementiri in historiis, ut aliquid dicere possint argutius, cf. 44; see DEN Hengst 97f., who notes that in both Brutus 42 and Aur. 2 amusement is explicitly mentioned (ridens and iocando).
} 
frequentavit (A 35.1). Fides crops up for the last time in $Q T$ (15.9): ne quid fidei deesset, etiam de his, quae didiceram, intimanda curavi.

The author knew that the Trebellius whose name he borrowed as an upholder of fides historica was not a fidei patronus at all, but a fraudator creditorum. He was having fun. ${ }^{33}$ This is confirmed by looking at the name 'Vopiscus'. Domaszewski plausibly suggested that it too was inspired by Cicero, Phil. 11.11, alter Caesar Vopiscus, while the origin of 'Flavius Vopiscus', 'Syracusius', was chosen because of the Verrines, full of references to Syracusae and Syracusani.$^{34}$ His case can be strengthened: Cicero's reference to Vopiscus comes just before one to L. Trebellius. Caesar Vopiscus ${ }^{35}$ was referred to by Cicero because he stood for the consulship (in $88 \mathrm{BC}$ ) when only ex-aedile; Calpurnius Bestia, here attacked, was trying to do the same in 43 BC, hence was 'a second Caesar Vopiscus.' The real Caesar Vopiscus was much admired by Cicero, as is clear here. What is more, in the Brutus 177, Tusc. 5.55 and Off. 1.133, he praised his wit; and, better still, he chose him in De oratore, 2.217-297, to define iocus et facetiae, ridicula et salsa. As for 'Syracusius', the explanation is indeed in Cicero, not in the Verrines, but in the De oratore, as spotted by Reekmans: '[the author was] writing under different pseudonyms, among them Flavius Vopiscus Syracusius (reminiscent of Strabo Vopiscus, Cicero's main authority on humour in De Oratore II, and referring to the reputation of Sicilians in the field of humour, cf. D.O. II 217), [and] pretending to be a contemporary of Diocletian, Constantius I and Constantine, ... giving on occasion a knowing wink to readers who knew that he was unreliable. ${ }^{36} \mathrm{He}$ cites for 'knowing wink' a string of passages in lives by 'Pollio' and 'Vopiscus' asserting devotion to fides, fidelitas historica or related virtues. ${ }^{37}$

${ }^{33}$ On humour in the HA see T. Reekmans, Ancient Society 28 (1997) 175-207.

${ }^{34}$ Domaszewski 11f. A. Chastagnol, HAC n.s. II (1994) 91, suggested, without reference to Domaszewski, that 'Caesar Vopiscus' in Phil. 11.11 may have inspired the choice of 'Flavius Vopiscus'; he noted, 90f., an echo of Phil. 11.10.

${ }^{35}$ The name 'Strabo' is known only from ILS 48, and 'Vopiscus' does not occur frequently. According to Marius Victorinus (Gramm. 6. 8.8 Keil), Strabo Vopiscus apparently acquired yet another name: 'Sesquiculus', meaning a man whose buttocks are too large by one half. Presumably that nickname was someone's revenge: Vopiscus specialised in raising a laugh by pointing out his opponents' physical peculiarities, cf. De orat. 2. 266, discussed by Quintilian, Inst. 6.3.38.

${ }^{36}$ Reekmans 176 and n. 6. I am grateful to François Paschoud for drawing my attention to this article. Strabo Vopiscus commented: inveni autem ridicula et salsa multa Graecorum - nam et Siculi in eo genere et Rhodii et Byzantii et praeter ceteros Attici excellunt (De orat. 2.217).

${ }^{37}$ Reekmans 197-9. For a fuller version of the above discussion of 'Pollio' and 'Vopiscus' see A.R. BIRLEY, HAC n.s. VIII (2002) 33-47. 
Paschoud has recalled a remark once made to him by Momigliano: 'La Storia Augusta ride, Zosimo piange'. But after quoting Syme on the author's 'delight in deception for its own sake', ${ }^{38}$ Paschoud comments: 'Ritengo però che il desiderio di divertire non sia l'unico scopa dell'impresa. L'anonimo non ride sempre, e quando ride, si può talvolta ammettere che non fa altro che ridens dicere verum [quamquam ridentem dicere verum/ quid vetat? Horace, Serm. 1.1.24f.?]'.39

What was the point? The best explanation, in my view, is that offered by Paschoud: a 'réaction de l'auteur de l' $H A$ face au christianisme triomphant... Les païens méritent d'être tolérées, parce qu'ils ont été tolérants quand ils étaient les plus forts, et par ailleurs parce qu'ils ont été, et restent, aussi vertueux que les chrétiens: Alexandre Sévère, qui a préfiguré Julien, ou Apollonios de Tyane, qui n'est pas inférieur à Jésus. En revanche, celui qui, le premier, s'est détourné des rites traditionnels, Constantin, a été préfiguré par un prince infâme, Elagabal.' Elsewhere he writes: 'en sa partie finale du moins, l'Histoire Auguste est une sort de conte philosophico-historique qui transmet, peu après 395, à un cercle de lecteurs bien précis une vision alternative, politiquement incorrecte, de l'histoire. La collection s'achève... à l'aube d'un jour glorieux, au moment où se lève le soleil de la tétrarchie, car l'auteur identifie le hier de 284 avec l'aujourd'hui de 395, à un siècle de 110 ans de distance, et affirme, par une sorte de métaphore chronologique, qu'il n'y a pas lieu, comme les chrétiens, et en parfait contradiction avec toutes les traditions nationales, de fixer son regard sur le point oméga d'un hypothétique salut hors du temps, mais bien, hic et nunc, d'attendre la prochaine régénération d'une Rome traditionelle qui, depuis plus de mille ans, s'est toujours ressaisie après ses pires malheurs. ${ }^{90}$

${ }^{38}$ Syme, Emperors $15 \mathrm{f}$.

${ }^{39} \mathrm{~F}$. PAschoud, in I cristiani e l'impero nel IV secolo (1988) 159.

${ }^{40}$ F. PAschoud, Cristianesimo nella storia 11 (1990) 570f.; id., Vies de Probus...XXVf. Cf. also id., in I cristiani e l'impero 159: the HA as a kind of discourse 'nella quale si possono dire ed esemplificare in un modo convincente tutte le cose impossibili di esprimere in un'opera storiografica tradizionale.' 
Abstract. The paper first summarises present views about the sources of the Historia Augusta. The structure of the work is discussed; possibly both the lack of preface and the 'lacuna' for the years 244-260 were deliberate. Much of the work is fiction, particularly in the 'secondary lives' and those of third-century figures. The fictional passages, in which the history of the period before Diocletian was re-written, are important for understanding the mentality of the unknown author: he was hostile to Constantine and Christianity, but greatly admired of Diocletian. There are many signs of humour, in particular the pseudonyms 'Trebellius Pollio' and 'Flavius Vopiscus Syracusius', the choice of which is explained. But in spite of these jokes, the author was still serious in longing for a second Diocletian to arise, who could restore the traditional values and religion of ancient Rome.

KEYwords. Historia Augusta; factual sources; fictional history; hostility to Constantine and to Christianity; admiration for Diocletian; fond of humour; choice of pseudonyms a sign of humour; longing for a new Diocletian and a pagan restoration. 